\title{
3
}

\section{The European Trade Union Movement and the Issue of Statutory Minimum Wages}

\begin{abstract}
Most countries in Europe have minimum wage legislation, but there are some exceptions such as the Nordic countries. The issue has clearly divided European trade unions and Nordic unions represent a foothold for the resistance to this kind of regulation. To provide a more detailed picture of European labour organizations' arguments for and against minimum wage legislation, data from interviews and surveys as well as documents are used. There is obviously a deep cleavage within the European trade union movement and the chapter also describes how the ETUC has handled the diverging positions.
\end{abstract}

Keywords Statutory minimum wages . Trade union disagreement . ETUC compromise

\section{Introduction}

We now turn to a topic that has caused a great deal of debate within the European trade union movement: the issue of statutory minimum wages. Most Nordic trade unions as well as some others take a negative view on minimum wage legislation-in sharp contrast to many other organizations in different parts of Europe (e.g., Eldring and Alsos 2012: 84-87;

(C) The Author(s) 2020 
2015; Furåker 2017; Furåker and Bengtsson 2013: 172-173; Furåker and Lovén Seldén 2013; Schulten 2008: 434; 2014; Schulten et al. 2015: 345-350; Seeliger 2019: 54-61, 155-172; Vande Keybus 2012). Because of these differences of opinion, the issue has been repeatedly debated within the ETUC that has faced difficulties in finding a common policy on the matter. It seems, however, that the issue was settledat least temporarily_-some years ago. The present chapter describes parts of the discussion.

Our purpose is to examine somewhat more closely the arguments for and against statutory minimum wages and how the ETUC has handled the issue. We make use of various kinds of data derived from interviews, surveys and documents. Data were collected in our two research projects described in Chapter 1 of this book. To begin with, we briefly outline some of the characteristics of minimum wage legislation in Europe. Then there is a section on the principal pros and cons of statutory minimum wages, commonly brought forward by trade unions. For the purpose of describing these opinions, interviews with trade union officials are particularly important. After that we report a series of relevant results from our two surveys. Several questions referred to the organizations' attitudes to statutory minimum wages, among other things whether they could see advantages and disadvantages with legislation. Next we turn to the cleavage in the European trade union movement and how the ETUC has managed to reach a compromise. The chapter ends with a concluding discussion.

\section{Statutory Minimum Wages in Europe: A Brief Background}

Most EU Member States have legislated minimum wage levels; there are only six exceptions: Austria, Denmark, Cyprus, Finland, Italy and Sweden (Eurofound 2019b). Both Cyprus and Italy appear to be on the road to introduce statutory minima. In Cyprus there is occupationspecific statutory minimum wages for some and collectively agreed minimum wages for others. Austria has had a debate on the issue, but so far kept its system relying on collective agreements. Iceland, Norway and 
Switzerland, which are not members in the EU, have no legislation. It should be added that both Iceland and Norway, as well as Finland, admit extension of collective agreements by law, although in the Norwegian case this option has been less often made use of (Eldring and Alsos 2015: 71-78). Denmark and Sweden do not have statutory minimum wages or any erga omnes rules. Germany is currently the most recent country to have adopted legislation. This occurred in 2015 through a political decision in spite of some criticism from the social partners (Eurofound 2019b: 2).

There are significant differences among the countries with legislation as to the levels of statutory minimum wages (Eurofound 2019a). Luxembourg has the highest level—nominally more than seven times higher than Bulgaria, which has the lowest. The rough general pattern is that the highest figures appear in North Western European countries and the lowest in the East with the South in between. Most countries have had increases in real terms since 2010, in particular Romania, Bulgaria and Lithuania. In some cases, especially France, Malta and the Netherlands, the increases are small and for Greece and Belgium we actually discover a decrease.

With huge differences in living standards across Europe we could expect to see more or less corresponding cross-national differences in the levels of statutory minimum wages. Therefore the so-called Kaitz index is perhaps a more interesting piece of information. This indicator measures the ratio between the legal minimum wage and the average (mean or median) wage in a country. From the OECD database, we can convey information on the Kaitz index 2017 among EU Member States. In relation to median wages of full-time workers, it was highest for France and Romania (both with 0.62), followed by Portugal (0.61) and the lowest figures turned out for Spain (0.40), the Czech Republic and Estonia (both with 0.41 ). Measured as a proportion of mean wages for full-time workers, France is still at the top (0.50), ahead of three countries with 0.44: Poland, Romania and the United Kingdom. At the bottom, we find Greece (0.33), Spain (0.34) and the Czech Republic and Estonia (both with 0.35).

Another indicator is the proportion of workers being paid at the level of statutory minimum wages or even lower (Eurofound 2019a: 23-24). 
It varies substantially across Europe. Poland has the highest proportion (13.7\%), followed by the United Kingdom, Luxembourg, Germany and Portugal with figures above $10 \%$. The lowest proportions appear for the Czech Republic (2\%), with Malta, Belgium and Croatia just a little bit higher.

In 12 of the EU Member States, there are special rates for certain categories (Eurofound 2019a: 26). Mostly these special rates apply to younger or less-skilled workers. The goal is to make these workers more attractive in the labour market by letting employers hire them to lower costs than would be the case with the ordinary statutory minimum wages. In some countries, for example Hungary, there are higher rates for skilled employees.

Some recent research in Europe covers the relationship between statutory minimum wages and such aspects as working hours and employment (Eurofound 2019a: 34). We have access to new studies on these topics in Germany, Greece and Ireland (Bonin et al. 2019; Bruttel 2019; Caliendo et al. 2018; Georgiadis et al. 2018; McGuiness and Redmond 2018). The general result is that the impact on employment has been small. Legislation has led to an increase in hourly wages, but it has also tended to reduce working hours. When Ireland increased the minimum wage level with $6 \%$ in 2016 , it led to a substantial decline of working hours, especially for those with temporary employment contracts (McGuiness and Redmond 2018).

An interesting case is Germany that implemented minimum wages legislation in 2015. With a high level of minimum pay, the new regulation apparently has favoured 'low educated, marginally employed, women and people with migration background' (Caliendo et al. 2018: 30). At the same time, overall employment appeared to have undergone a slight decrease, due to diminished recruitment and a decrease of marginal employment, that is, so-called mini-jobs. No clear effects were found on people's livelihood, because there was also a clear reduction in working hours. Poverty and inequality were therefore not much affected. Finally, available evidence pointed to a significant non-compliance with the rules; large numbers of employees were paid less than required by law. 
Another German study found rather similar results (Bonin et al. 2019). After two years there had been a reduction of marginal employment, but the researchers could not confirm any significant changes in regular employment and unemployment. One factor that should not be neglected is that people who previously had mini-jobs to some extent had become self-employed and therefore stood outside the minimum wage legislation.

A third study also found that the increase of hourly wages did not imply higher monthly pay, as there was a parallel reduction of working hours (Bruttel 2019). Companies that paid less than the minimum wage level before 2015 increased their prices, but nonetheless got lower profits. However, the effects of the legislation on the overall economy appeared to have been limited. Furthermore, the problem of non-compliance was again emphasized; it remained a crucial task to ensure better compliance. Yet another conclusion was that people's welfare dependency and risk for poverty did not diminish.

An interesting question is whether the bottom level is set sufficiently high to avoid poverty. The statutory minimum wages in many European countries are so low that they do not prevent income poverty (Schulten 2014: 13). It should be noted that the percentage of working poor is generally lower in the Nordic countries as well as in Italy than elsewhere in Europe (Eldring and Alsos 2015: 34-36; Schulten 2014). As a consequence, it may not be so easy to convince trade unions in these countries that legislation is necessary to avoid in-work poverty.

\section{Arguments for Legislated Minimum Wages}

Trade unions can have different motives for taking a certain position in the debate on statutory minimum wages. It is unclear to what extent empirical studies in the field have an impact on the debate. Unions' motives may be more or less ideological or pragmatic and they can show more or less solidarity with various actors. In this and the next section we identify some of the most important arguments among trade unionists for and against minimum wage legislation. Indicators of these claims are 
also included in one of the empirical datasets (survey 2) that we use. We start with arguments about possible advantages.

Legislated minimum wages might secure that all workers-and not only the organized-are covered (Furåker and Lovén Seldén 2013; Schulten 2008; Schulten and Watt 2007). In one of our studies, a Spanish trade union official, interviewed in 2012, presented the argument in the following way (Furåker 2017):

The strongest argument for minimum wages is that it is necessary to protect all workers by one instrument... But it is not necessary to have it by law; it could just as well be by collective bargaining. This is a difference of culture, because in some other countries it is a tradition to protect only affiliates-perhaps 10, 20,30\%—and not workers who are not members. We come from a tradition in which the unions fight for all. In Spain we have $19-20 \%$ union density and $80 \%$ are non-members.

The assumption was then that employers comply with the minimum wage legislation. It is worth being repeated that studies of the German introduction of such legislation emphasized that there could be some substantial non-compliance (Bruttel 2019: 11-12; Caliendo et al. 2018: $30)$. Yet we can expect that even if not all unorganized employees are protected by law, some of them are likely to be. It can still be a fairly effective method of creating protection for the unorganized.

One thing to note is that the Spanish union official did not declare that legislation would be the only option; his opinion was that minimum wages could just as well be decided through collective bargaining. The point is, though, that if merely very few of the workers are unionized, a majority may not be protected by collective bargaining - unless there is extension of collective agreements by law.

Two German trade union representatives who were interviewed together said that they would prefer wages be set through collective bargaining, but if this was not feasible, other solutions must come in (Furåker and Lovén Seldén 2013: 514). What they actually referred to was minimum wage legislation. This should be seen in light of the declining union density rate in Germany like in many other countries, implying that more and more employees stayed unorganized. 
Another Spanish union official, who was interviewed in 2012, also stressed how important it would be with minimum wage legislation to protect workers, but he brought up yet another principal argument by pointing out that minimum wage legislation establishes a clear limit to wage dumping (Furåker and Lovén Seldén 2013: 514): 'The second reason may be that if you have a minimum wage you have a limit to wage dumping'.

This argument was also mentioned in several other interviews that we conducted in our two research projects (cf. Vande Keybus 2012). Again, a crucial problem is whether employers comply with the legislation, because non-compliance can be interpreted as just another expression for wage dumping. It is at least likely that statutory minima establish some limits to dumping of that kind. Therefore, they might be seen as measures to decrease inequalities in society (Schulten 2008; Schulten and Watt 2007; Vande Keybus 2012).

A mechanism that helps prevent wage dumping may also contribute to decreasing poverty. The German studies referred to above (Bruttel 2019; Caliendo et al. 2018) did not find this kind of effect, but the poverty-reducing impact of statutory minimum wages has still often been brought forward as a positive argument in the debate. Sometimes it has been proposed that minimum wage legislation should help people get a 'living wage' (Schulten 2008; Schulten et al. 2015: 339-341).

We should keep a distinction between minimum wage legislation at national level and such regulation at European level. National legislation already exists in many countries, but could be extended to countries without legislation. It is also possible to make rules stricter and more difficult not to follow. In addition, there is the question about the minimum wage levels in relation to the general wage situation in a country. At European level, no regulation of minimum wages exists, but it might be implemented in different ways. There are many advocates for introducing a common European policy in this regard (Eldring and Alsos 2015: 13-21; Fernández-Marcías and Vacas-Soriano 2016; Schulten 2008, 2014; Schulten and Müller 2014; Vande Keybus 2012; Vaughan-Whitehead 2010). This is a more far-reaching idea, which might be especially difficult to accept for unions with a negative attitude even to national legislation. It is of course unrealistic with a single 
minimum wage level throughout the EU. What is closest at hand would be to implement an EU directive according to which statutory minimum wages should be set at, for example, $60 \%$ of the average wage in each Member State (cf. Schulten 2014). In the following, both of these dimensions will be touched upon. First, we proceed to describe possible arguments against minimum wage legislation, with primarily a nationallevel focus.

\section{Arguments against Legislated Minimum Wages}

From previous research and various documents, we can outline the main arguments behind trade unions' negative views on statutory minimum wages. On the whole, the countries without statutory minimum wages appear to have a viable option. The Nordic countries have high union density rates and a high degree of collective bargaining coverage, although there is some variation between them. This is true even though union density tends to fall everywhere in the Nordic region except Iceland. Other countries without minimum wage legislation have lower density rates and lower levels of collective bargaining coverage, but compared to many other countries they still score relatively high in these respects.

Legislation on minimum wages is regarded as a restriction on the partners' freedom to conclude independent agreements (Eldring and Alsos 2015: 85). When we interviewed highly placed officials in the Swedish trade union confederations some years ago, the principle of independent collective bargaining was energetically stressed as being very important. Such an opinion was communicated very distinctly in an interview with a Swedish trade union official (Furåker and Lovén Seldén 2013: 514).

The main argument against [a minimum wage policy] is that it contradicts our strategy of organizing, negotiating and signing collective agreements and monitoring whether the collective agreements are respected, and by doing so taking control over the destiny of workers... To act as a 
supply cartel is simply... a fundamental traditional trade union view. To support a statutory minimum wage is a strong violation of that tradition.

Moreover, it seems that the Nordic trade unions are also afraid that an acceptance of minimum wage legislation would be followed by further European regulations (Eldring and Alsos 2015: 84). They simply want to safeguard the Nordic model with its emphasis on the autonomy and integrity of collective bargaining.

We may ask whether or not collective bargaining leads to better results for workers. Minimum wage legislation should at least maintain a lowest limit, unless employers fail to comply with the law. A relevant piece of information in this context is brought up by Line Eldring and Kristin Alsos (2015: 74-78, 85); they make the observation that, in selected key industries in the Nordic countries, wages significantly exceeded the agreed minima. This outcome applied also in industries with low collective bargaining coverage. The explanation is held to be a contagion effect of collective agreements. Legislated minimum wages can then be a blow in the air and this is not all: their consequences may even go in the opposite direction. Actually, it is a possible disadvantage recognized by some of those arguing for legislation as well. One of our interviewees, from a Belgian trade union, pointed out that because legislation would set the lowest pay level, it could be difficult to obtain a higher wage than that (Furåker and Lovén Seldén 2013: 515). The same opinion was expressed in another interview with a Spanish union official (Furåker and Lovén Seldén 2013: 515):

Once you have a minimum wage, sometimes it can be very difficult to improve a lot on that minimum wage. So you have your minimum wage and that is okay, but [it] can be difficult to have improvements on that because that is the economic reality... and I suppose that would be the main reason against it.

It should be noted that the Belgian and the Spanish unionists just mentioned were both strongly in favour of legislation. A further possible disadvantage with state regulation of minimum wages is that it could weaken employees' motivation to become unionized (Eldring and Alsos 
2015: 85-86; Furåker and Lovén Seldén 2013: 515). It is always a critical issue for trade unions to recruit members, and this will certainly not be made simpler if wages are set without unions having very much to say. This reasoning could be relevant in relation to employer organizations too. However, unions (and employers' associations) may have a role in contributing to deciding the legislated minimum wages. Thus, unions could get a more visible role at societal level, even if this would be restricted to peak-level organizations (Furåker and Lovén Seldén 2013: 515; Vande Keybus 2012).

In the last two sections, we have brought up a number of possible advantages and disadvantages of statutory minimum wages. The ambition has not been to provide an exhaustive description, but we have tried to focus on rather tangible aspects. There are other aspects that could also be mentioned, for example, that a joint position among trade unions on European minimum wage legislation could have an important symbolic value, 'giving substance to Social Europe' (Vaughan-Whitehead 2010: 529).

\section{What Do Survey Data Tell Us?}

In our two surveys, we have some questions concerning statutory minimum wages. As to the 2010-2011 survey we limit the presentation to countries in which the number of responding unions exceeded 10, which means results for 11 countries. The questionnaire included a number of items intended to gauge attitudes to minimum wages. Respondents were asked to what extent they agreed with certain statements - to a high degree, to some degree, to a low degree ${ }^{1}$ or not at all.

The first statement says that it would require EU legislation on minimum wages to prevent wage dumping. The second item taps the desirability of future developments of national legislation on minimum wages, either through the introduction of such legislation (if it does not exist) or through stricter legislation (if it already exists). Union representatives were accordingly expected to interpret the statement in accordance with their own location. The third item in the questionnaire deals with the 
issue whether, at transnational level, it would be desirable in the future with European legislation on minimum wages.

Table 3.1 presents the summary indicators for the 11 countries on each of the items. Summary indicators are calculated in the same way as in two of the tables in Chapter 2 (Tables 2.1 and 2.3). Starting with the first statement, we should note that at this time not only the four Nordic countries were without minimum wage legislation; this was also the case for Germany. It is striking that all the responding unions in Belgium, Poland and Spain agreed at least to some degree that it would take EU legislation on minimum pay to prevent wage dumping. The summary indicators for France and Germany are slightly lower because some unions deviate from the common pattern. Still, in both cases a clear majority of unions expressed a great deal of agreement with the statement. The United Kingdom comes next in the ranking with a lower level of agreement, but still with a markedly positive score after the summary indicator calculation. Finland also gets a positive end result, but it is not very far from zero. For the remaining Nordic countries, Denmark, Norway and Sweden, the summary indicators are negative. Denmark is not so distant from Finland, while Sweden is undoubtedly farthest away.

The response pattern on the second item is fairly similar to the first one, but there are some differences. Instead of Belgium, Poland and Spain at the top, we find Germany, Poland and Spain. We can add that $90 \%$ of the 20 Polish respondents agreed 'to a high degree' (not shown), implying that they would like to have stricter legislation. For Spain, the result goes in the same direction, but with a much lower proportion answering 'to a high degree'. As to Germany, the outcome suggests that national legislation on minimum wages was, more or less, on the unions' wish list. In Belgium, three out of eleven trade unions did not select the two most positive response options and this was the case for five out of eighteen French organizations as well. Hence, the summary indicators in the two countries are quite similar. An interpretation of this is that many respondents were fairly satisfied with the national minimum wage legislation; they did not find it desirable to make it stricter. The British unions emerge as more divided. For the Nordic cluster, we see strongly negative figures in the summary indicator column. Notably, the proportions 


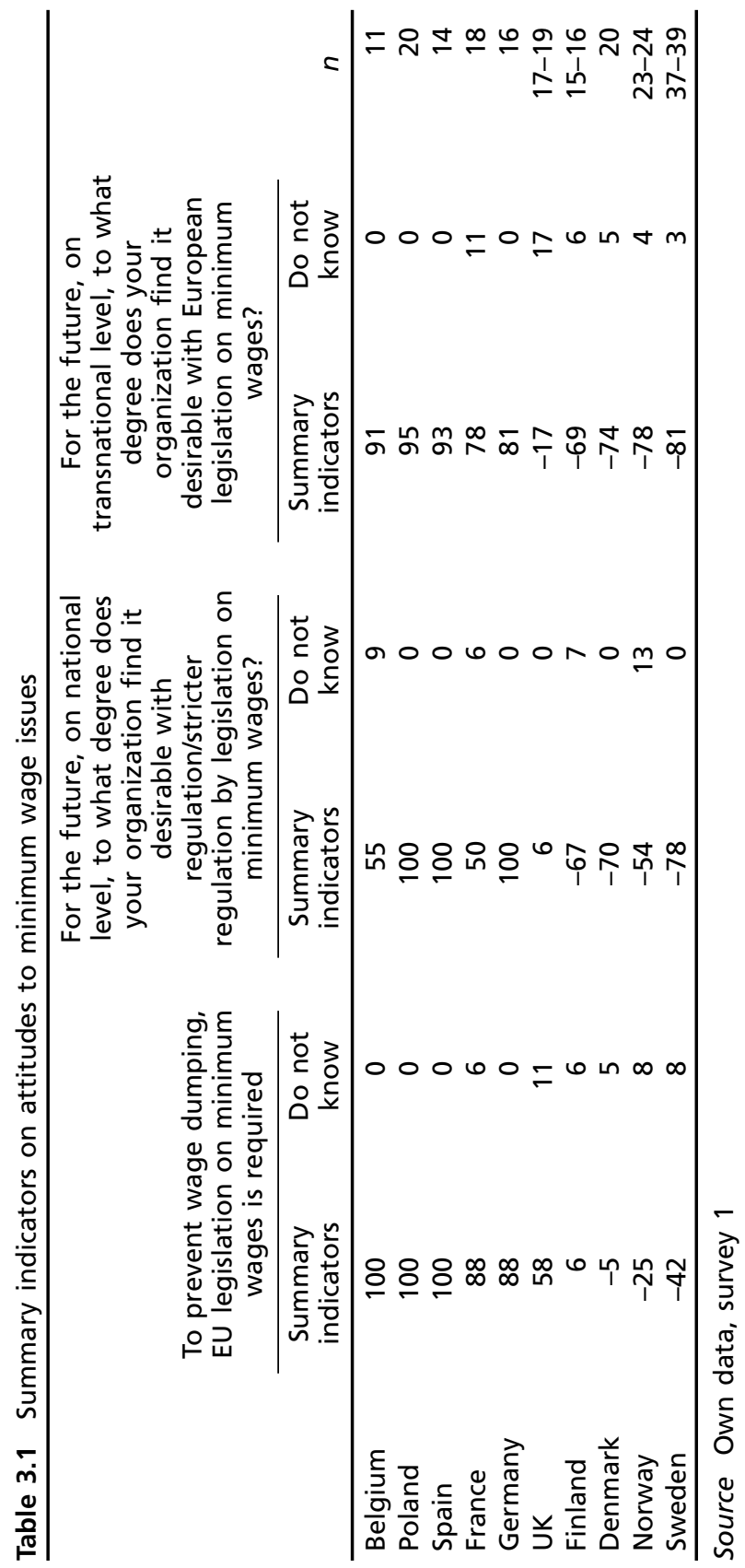


answering that they did not agree at all are particularly high in Sweden and Denmark.

The final item in Table 3.1 deals with the issue whether it would be desirable in the future with European legislation on minimum wages. The highest summary indicators-for Poland, Spain and Belgiumare then slightly below 100, as a few trade unions in these countries expressed doubts about such an arrangement. German and French respondents also appear with high positive figures. The British unions have a negative summary indicator, although far from the Nordic unions, which all show very little consensus on the idea of future European legislation.

With respect to our 2015-2016 survey we have answers from 221 trade unions. The survey contained seven questions with relevance for the minimum wage issue or-to be more specific_-statements on which respondents were asked to express their organizations' view. The overriding question was: 'To what degree does your organization agree with the following statements on nationally legislated minimum wages?' Six of the items include statements that can be regarded as arguments for or against national legislation. They gauge whether statutory minimum wages (a) 'are necessary to prevent wage dumping'; (b) 'undermine the role of trade unions'; (c) 'are the best way for unorganized workers to get decent wages'; (d) 'are necessary to prevent poverty'; (e) 'make it more difficult for unions to recruit members' and (f) 'may lead to lower collectively agree wages'. The seventh statement was aimed at exploring attitudes to a possible role for the ETUC and has the following wording: 'ETUC should work for common European norms on minimum wages'. Each of the seven items could be answered in the same way as reported for the items in Table 3.1.

Three of the statements thus represent possible advantages with statutory minimum wages and three others represent possible disadvantages. In the following, we divide the trade unions into three categories. One consists of those in countries with legislated minimum wages and then we have two categories in countries without such legislation: non-Nordic and Nordic. The reason why we treat the Nordic unions separately is that they are frequently depicted as the most negative to political regulation of 
wage setting (e.g., Furåker 2017; Eldring and Alsos 2012, 2015; Schulten et al. 2015; Seeliger 2019: 155-172). As a consequence, we have only 17 respondents from unions in other countries without legislation, but without this distinction certain interesting differences would not become visible. Table 3.2 gives the responses on the first set of statements, dealing with conceivable advantages with legislation.

As we can see, unions in countries with minimum wage legislation were much more inclined to endorse the statements that contain the arguments in support of such arrangements. This comes out clearly, when we concentrate on the summary indicators. They are strongly positive for unions in countries with statutory minimum wages, but there are some differences between the items: a very high score for the statement regarding wage dumping, distinctly lower on the item regarding the consequences for unorganized workers and somewhere in between for the avoid-poverty statement. There are of course unions, which have expressed a deviant opinion, but they are not that many. For trade unions in non-Nordic countries without statutory minimum wages, the corresponding scores are all much lower, but two out of three are still positive. The exception with a low negative number is the item on legislation as the best way for unorganized workers to get decent wages. In contrast, we find large negative figures for the Nordic trade unions, roughly varying between minus one-third and minus 40 on the summary indicators in the three cases.

Table 3.3 presents the response patterns regarding arguments against statutory minimum wages. In these cases, trade unions in the countries with minimum wage legislation have strongly negative summary indicators. With some variation, this holds for all three items in the table. It seems that these respondents did not generally believe that legislation would undermine the role of unions nor make it more difficult for them to recruit members or that it would lead to lower collectively agreed wages. Again, there are organizations that have responded differently, but very few answered that they agreed 'to a high degree' with these negative statements.

For the unions in non-Nordic countries without legislation, a somewhat different pattern comes out. These organizations have two rather low, but still positive summary indicators: on the first and on the third 


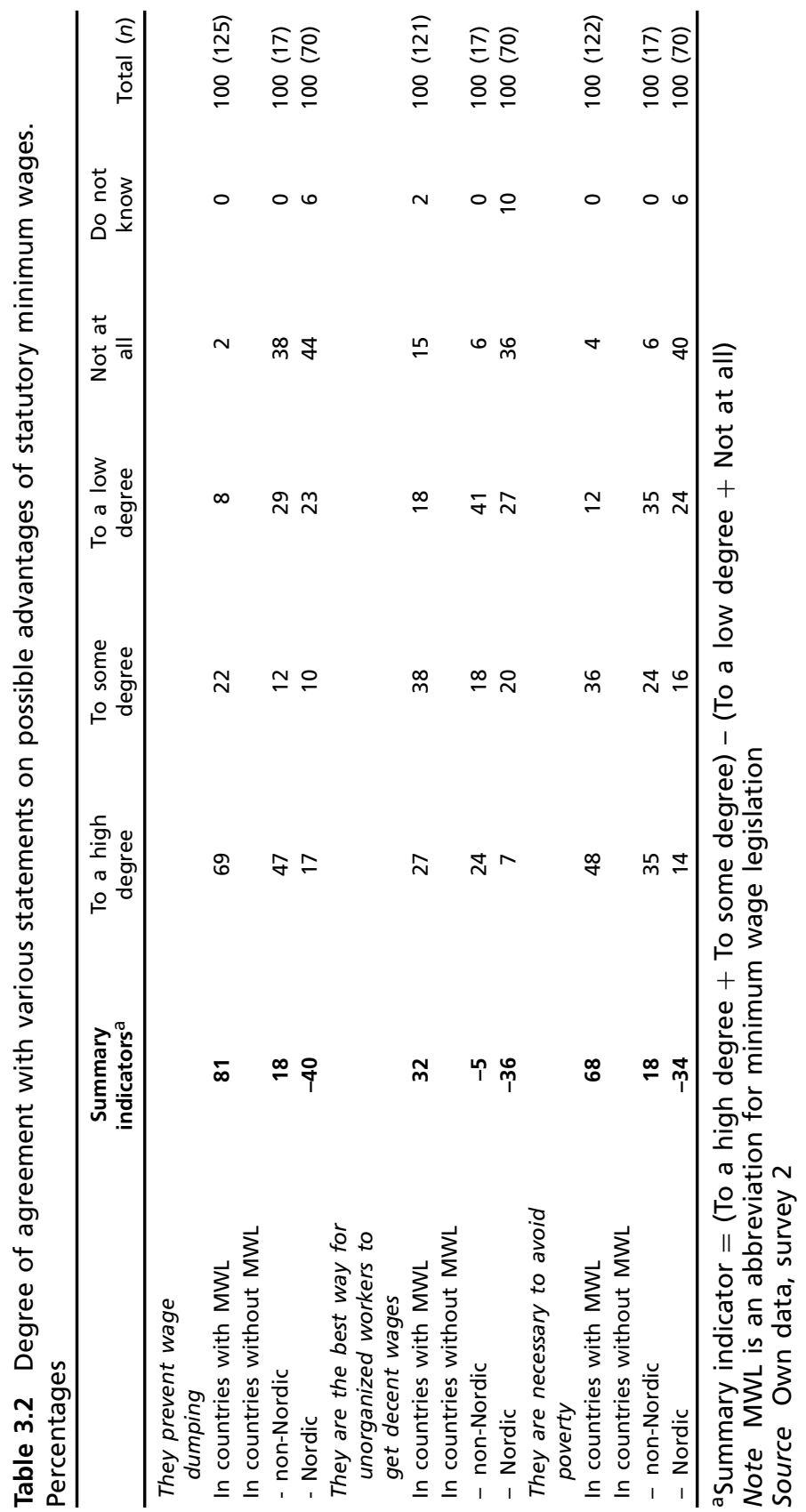




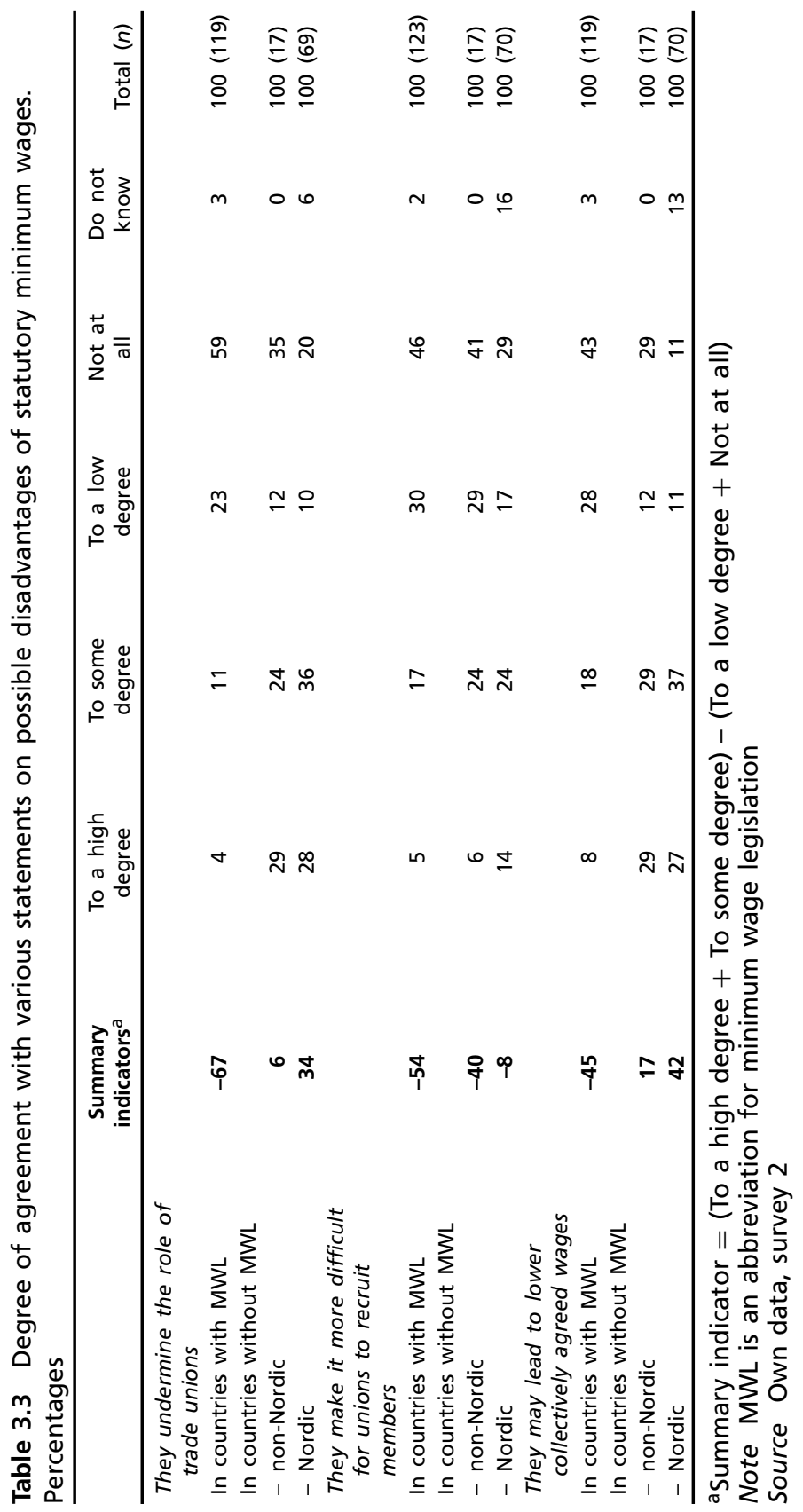




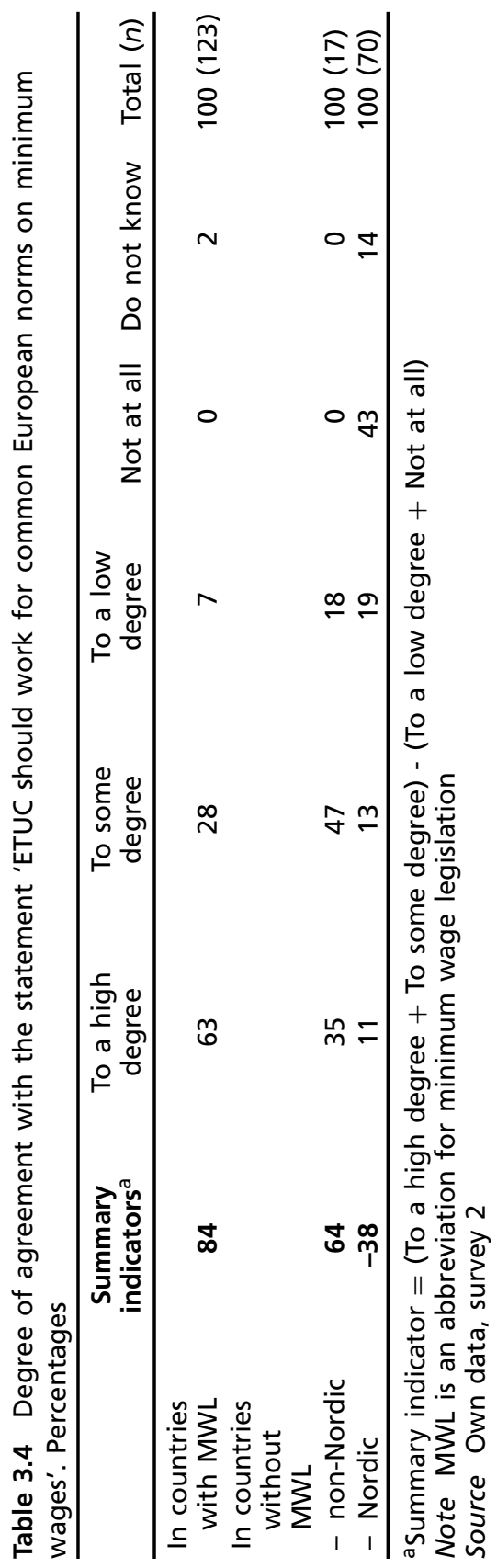


statement. For them, the second item is an exception with a highly negative balance, not so far from what we see for unions in countries with statutory minimum wages. The Nordic unions also get a negative summary indicator on this statement, even if it is much closer to zero. In other words, most of the responding organizations did not find that legislation would make it more difficult for them to recruit members. With respect to the first and the third item, the Nordic unions generally agreed to a high or some degree with the presumed disadvantages. We could note that the proportions of 'do-not-know' answers are especially high in the Nordic cluster. Although partly with lower numbers, this also applies to Table 3.2.

On the seventh item in the questionnaire-on whether the ETUC should work for common minimum wage norms in Europe-most trade unions in countries with legislation responded in the affirmative, as we can see in Table 3.4. There is not much doubt on the topic among these organizations; most of them at least appeared to be sure about one thing to which the ETUC should devote its power.

The non-Nordic unions in countries without legislation also tended to agree with the statement, although the summary indicator is somewhat lower. In contrast, the Nordic respondents provided a very different set of answers, adding up to a distinctly negative summary value, but $14 \%$ replied that they did not know.

\section{The Cleavage in the European Trade Union Movement}

Our examination of data points to a distinct conclusion. While many unions in Europe are strongly in favour of minimum wage legislation, others and especially Nordic unions are very negative to it (Eldring and Alsos 2015; Furåker and Lovén Seldén 2013; Furåker 2017; Schulten et al. 2015; Seeliger 2019: 155-172). Typically, in the Nordic countries this kind of arrangement is at best considered to be 'a necessary evil' (Eldring and Alsos 2015). In other words, there are rival views on the topic in the European trade union movement. The Nordic trade unions may seem to be united in their resistance to minimum wage legislation, 
but we should note some cracks in the facade. Also in this region we find some differences of opinion and some disagreement. As the summary indicators presented above are never 100 or -100 for the Nordic unions, some of them must have responded in another way than the majority. Moreover, the proportions of 'do-not-know' answers turned out to be highest in the Nordic cluster. Anyway, some Nordic unions were evidently not very negative to legislation or could not take a stand.

A much talked about event took place in 2014 in Copenhagen, where the ETUC Executive Committee held a meeting. Bente Sorgenfrey, Chairperson of the Confederation of Professionals in Demark, President for the Council of Nordic Trade Unions and member of the ETUC Executive Committee, then spoke in favour of statutory minimum wages (Eurofound 2015). After bringing up her arguments at a press conference there was an immediate and massive reaction from both other Danish unions and Danish employers' associations, which all emphatically said no thanks to minimum wage legislation. This was not the only time that Sorgenfrey was in focus. Nordic Labour Journal (2015: 3-7) had a thematic issue on statutory minimum wages and there she was quoted, highlighting that many European colleagues advocated European minimum wage legislation and arguing that Nordic trade union leaders should support them. She was also reported to mention that the Norwegian model with the possibility of extending collective agreements by law could be a reasonable way forward.

Another example of differing Nordic opinions stems from the Swedish Transport Workers' Union. This organization raised the issue of making collective agreements into law (Nordic Labour Journal 2015: 14-15) at about the same time as Sorgenfrey came out with her views on the delicate question. In an interview, conducted within our second research project in 2015, the chairman of the organized transport workers noted that this initiative was 'not popular in the $\mathrm{LO}^{2}$ ', in spite of his argument 'that we are in the industry that has been most exposed to social dumping' - which, he said, would require some action.

Albeit these examples, a Nordic comparison showed that the Danish and Swedish trade unions were the most negative to minimum wage 
legislation (Furåker 2017). The analysis also revealed that larger organizations were less prone to see advantages with legislation and large organizations are of course relatively influential in the cooperation within the ETUC.

It should not be very surprising that unions in countries where statutory minimum wages exist are more likely to see advantages with legislation than are unions in countries without such measures. Obviously, the reverse also applies. The most important observation is, however, that the diverging opinions create conflicts in connection with transnational trade union cooperation. The continuing resistance to state regulation among Nordic trade unions makes us quote three other researchers asking why 'the apparently robust and sustainable Nordic labour market regimes could feel threatened by a European minimum wage policy that is intended primarily for countries with low minimum wage levels or no functioning minimum wage regimes' (Schulten et al. 2015: 350). The answer is most likely a fear among the Nordic unions that their own model would be negatively affected by legislation and that acceptance of it might be the first step towards further European regulations (Eldring and Alsos 2015: 84).

We may also ask whether the concept of solidarity is relevant. Rebecka Gumbrell-McCormick and Richard Hyman (2015; Hyman 2002) have shown that this concept can be interpreted in different ways. Among other things, the point of departure for trade unions is that workers' interests need to be taken care of by a collective organization. There is also a distinction between solidarity with and solidarity against (Gumbrell-McCormick and Hyman 2015: 2). A typical example can be when workers feel solidarity with one another and against employers. As to the European discussion on statutory minimum wages, it seems that we find trade unions standing against each other. Whereas some organizations want to campaign for stricter national legislation, more generous minimum wage levels and perhaps a common European policy on the issue, others are simply against any such attempt. It is likely that both camps are fighting for those they feel solidarity with. The basis for the cleavage in the European trade union movement is the differences in organizational, structural and institutional power that exist 
between unions in different parts of Europe (cf. Chapter 1; GumbrellMcCormick and Hyman 2013: 30-31; Lehndorff et al. 2017).

Not least within the ETUC, we see these conflicting views colouring the debates over the years. Martin Seeliger (2019: 155-172) gives a vivid portrayal of the intense disagreements among European trade unionists on the issue of statutory minimum wages. Among other things, he interviewed a number of Hungarian, Polish and Swedish trade union representatives and these interview data are used as empirical evidence in his analysis. The Poles and the Hungarians were positive to minimum wage legislation and the Swedes were fervently against it. There were occasions when the debate was very heated, apparently with more solidarity against than solidarity with unions in other countries.

This also points at how important labour market policies and regulations are for transnational trade union cooperation. As shown in Chapter 2, differences in these respects were judged to be the second most important obstacle to such collaboration and similarities were considered the most important facilitator. It has simply been difficult to find a common cooperative basis for unions with respect to the issue of minimum wage legislation.

The ETUC is what Göran Ahrne and Nils Brunsson (2008) call a meta-organization, with other organizations as members (cf. also Lovén Seldén 2014: 30-31). One characteristic of meta-organizations is their tendency to search for consensus in decision-making (Ahrne and Brunsson 2008: 123-124). It is of great importance for building up legitimacy in relation to their members. We can see that the ETUC has handled disagreement regarding the issue of statutory minimum wages in line with this observation.

The minimum wage issue was on the agenda at the ETUC Congress in Seville in 2007. In a strategy and action plan, it was suggested, among other things, that the organization and its affiliated unions should work for the following (ETUC 2007: 138):

- Support union campaigns for effective minimum wages in those countries where the unions consider them necessary. Targets should be set as part of a purposeful campaign towards "living" wages and to tackle the growing gaps between rich and poor, men and women. 
- Targets to close the pay gaps should also be adopted by those unions whose confidence in the effectiveness of their collective bargaining processes means that they do not need legally established minimum wages.

- Explore continually the scope for united campaigns at European level, led by the ETUC, for common standards on minimum pay and income, and for collective bargaining strategies. Currently it may be that, for example, the differences in skills, productivity, living standards and union policies are too great for a campaign on common European-wide minimum wage mechanisms, but as circumstances change the ETUC must be ready to lead a debate on united campaigns.

We can notice that the ETUC balanced the disagreements within the organization. The idea is to support campaigns for minimum wage legislation only 'where unions consider them necessary'. Still, it was considered important to attack pay gaps also in countries where unions did not see a need for minimum wage legislation. In addition to this, it was argued that cross-national differences may be too great for 'a campaign on common European-wide minimum wage mechanisms', although things might change.

After the preparatory phase of the ETUC Congress in Athens 2011, there was a great deal of debate in the organization on minimum wages. It was important for the ETUC to avoid open conflict and the organization therefore needed to find a balance between different interests. In a previous article we compared various documents, showing certain changes of wordings (Furåker and Lovén Seldén 2013: 517, Note 6): In October 2011 the ETUC (2011a: 6) claimed that 'a minimum wage norm would be agreed determining the minimum pay level in each country', but only somewhat later, in December 2011, the organization stated 'that wherever it exists the effective national minimum wage should be at least equal to 50 per cent of the average wage or 60 per cent of the median wage' (ETUC 2011b: 6). The key words are 'in each country' and 'where it exists' and the latter wording is a remission to those who did not want legislation (Furåker and Lovén Seldén 2013: 517, Note 6). 
A stringent formulation of the ETUC position on statutory minimum wages, which also strikes the balance between the diverging interests came some years later (ETUC 2012a; cf. also 2013):

Wage setting [is] to remain a national matter and be dealt with according to national practices and industrial relations systems. Negotiations between social partners at the relevant level are the best tool to secure good wages and working conditions. The statutory minimum wage in those countries where trade unions consider it necessary should be increased substantially. In any event all wage floors should respect Council of Europe standards on fair wages.

The main idea in the above quotation is that national industrial relations systems and practices should have a crucial role in wage setting. The ETUC speaks in favour of collective bargaining as the best method of obtaining adequate wages and working conditions, but trade unions cannot always achieve their goals in that way. If that is the case, there is no other possibility but to rely on legislation. This is obviously the most relevant option for many European unions. What the ETUC did was to recognize that different solutions should apply in different national contexts.

Somewhat later, in the Paris Manifesto, the organization expressed the following opinion (ETUC 2015b: 8):

The autonomy of the social partners at national and European level must be respected. We reject interference by public authorities in social dialogue, collective bargaining or existing collective agreements. Industrial relations should be strengthened and collective agreements extended to cover as many workers as possible, with support for trade union coordination of collective bargaining.

This might even sound like a condemnation of all kinds of state intervention in the relationship between employers and trade unions, but there is also another paragraph (before the one quoted) in the same document, telling something else (ETUC 2015b: 8): 
Statutory minimum wages, where trade unions want them, should be set with the involvement of social partners. The level of a statutory minimum wage should aim for better standards, as advocated by international organisations. This, together with collective bargaining, will help to combat in-work poverty, social and wage dumping, and will foster internal demand. In this context, it is advisable to start discussions on a common reference for national statutory minimum wages, applicable in countries where trade unions want them.

Another aspect is that the ETUC does not believe that statutory minimum wages are sufficient to deal with labour-cost competition and inwork poverty. This is clearly expressed in the action program of 2015 (ETUC 2015a: 33):

Minimum wages alone cannot offer an adequate response to labour-cost competition and in-work poverty. Strengthening collective bargaining systems and their coverage is essential to prevent a downward slide in wage.

It is also recognized that it has been difficult to establish robust collective bargaining institutions in Central/Eastern Europe. Therefore, '/i/n these countries, minimum wages play a more important role than in others where well-established industrial relations systems are able to secure the best deal for workers'; in other words, 'a balanced and differentiated approach to minimum wages is needed, respecting national practices and needs' (ETUC 2015a: 33).

One important question is where to set the level of statutory minimum wages relative to other wages in a country. As pointed out above, in December 2011, just before the Copenhagen Winter School in February 2012, Copenhagen, the ETUC stated that the 'national minimum wage should be at least equal to 50 per cent of the average wage or 60 per cent of the median wage' (ETUC 2011b: 6). There was also an idea of an ETUC campaign on this topic, but it appears to have been delayed (Seeliger 2019: 56-57, 61, 163). A more recent ETUC (2018) resolution on coordination of collective bargaining and wage policies continues on the same path as before.

The Nordic trade unions have obviously been able to influence the ETUC's position on statutory minimum wages. One important factor 
behind this is the Council of Nordic Trade Unions. It has separate gatherings to make preparations for ETUC meetings (Seeliger 2019: 169$170,212-213,226)$. The participating organizations' discussions aim to find common positions on various issues and once they are united, they have been very successful in speaking with one voice. Attempts of such coordination in other regions have been less effective. When the Nordic subdivision has agreed on a certain position it is difficult for the ETUC not to take that very seriously.

\section{Conclusion}

The general picture in the above analysis is that Nordic trade unions as well as some others are sceptical, not to say absolutely against, of statutory minimum wages. This resistance exists in countries without minimum wage legislation, while the most affirmative attitudes are found in nations with such an arrangement. The majority of the unions in our surveys are located in the latter countries. Typically, they emerge as positive both on the more general questions and on the more specific items on advantages/disadvantages regarding statutory minimum wages. These respondents were mostly confident of claims that legislation is the best method for unorganized workers to obtain decent wages, that it can impede wage dumping and that it is a necessary arrangement to prevent poverty. The opposing unions did not agree very much on these statements. Instead, they were more susceptible to the potential drawbacks of minimum wage legislation. They tended to think that it undermines the role of trade unions and that it may lead to lower collectively agreed wages. A somewhat different outcome showed up on the issue of whether legislated minimum wages would have a negative impact on unions' possibilities of recruiting members. Some responding organizations agreed with this, but still more concurred only to a low degree or not at all. This goes for all the unions in our dataset, but the negative summary indicator for the Nordic unions is much closer to zero than for the other two categories in our analysis.

Another result is that the three categories of unions distinguished also differed with respect to the issue whether the ETUC should work for 
common European norms on minimum wages. These results are more or less in line with expectations. The Nordic unions were most negative, whereas the other two categories were basically positive, although unions in countries with statutory minimum wages were so to a greater extent. A similar pattern emerged on a couple of items dealing with EU minimum wage legislation in our first survey, but in this case the number of countries and responding unions was much smaller.

Our data indicate that the strongest opposition to minimum wage legislation comes from Nordic trade unions. Denmark, Finland, Iceland, Norway and Sweden undoubtedly show some significant similarities making them special compared with other countries, but there are also differences among them, for example, as mentioned previously, in regard of the possibility of extending collective agreements by law. A principal characteristic is that the Nordic countries have well-developed collective bargaining systems with strong social partners. One indicator of this is union density, which is high in international comparison. In 2017, Iceland had the highest level with over 90\% organized (Visser 2019). The corresponding figures in Denmark, Finland and Sweden were a bit below 70\%. In Norway, union density was around 52\%, still much above what we find in most other countries.

The Nordic bargaining system also has high proportions of employees covered by collective bargaining agreements. After adjustments for certain sectors and occupations excluded from the right to bargain, we again encounter quite high figures: for 2017, 93\% in Finland, $89 \%$ in Iceland and Sweden, 84\% in Denmark and 67\% in Norway (Visser 2019). Once more, the Norwegian figure is lower, but it is much higher than for union density in the country. All five Nordic countries have been shown to be above the OECD average in terms of collective bargaining coverage (OECD 2014: 103).

Hence, there are good reasons to distinguish a Nordic model of labour markets and industrial relations (Chapter 1 in this book; Dølvik 2013; Ferner and Hyman 1998; Larsson et al. 2012; Traxler et al. 2001; Visser et al. 2009). The literature also distinguishes four other industrial relations regimes, but it is not obvious that this classification can contribute to the analysis of trade union attitudes to statutory minimum wages. 
The divergent opinions within the European trade union movement have been associated with a great deal of debate. For the ETUC it was necessary to arrive at a settlement on minimum wages according to which it is recognized that different solutions are relevant due to national traditions and circumstances. The organization has even emphasized that collective agreements represent the best way to obtain good wages and appropriate working conditions, but that legislation can be necessary elsewhere (ETUC 2012a, b, 2013, 2015a, b). Most Nordic trade unions ought to be quite satisfied with the current ETUC compromise, because its main content is that wage setting should be adjusted to the national context. They have been able to achieve what they wanted to achieve. One reason behind this accomplishment is that the Council of Nordic Trade Unions is an effective sub-organization within the ETUC; it regularly acts unanimously and it is well-prepared for ETUC meetings (Seeliger 2019: 169-170, 226). It should be repeated that Nordic trade unions are characterized by having considerable organizational, structural and institutional power (cf. Chapter 1; Gumbrell-McCormick and Hyman 2013: 30-31; Lehndorff et al. 2017). As long as the ETUC compromise is valid, trade union cooperation in Europe does not have to be negatively affected, although it means that the struggle for legislated minimum wages is not a joint effort of European unions.

It seems that the classification into industrial relations regimes presented in Chapter 1 is of limited value when we examine trade unions' views on statutory minimum wages. The Nordic countries represent one of the five different regimes and in that sense the regime concept is relevant. Including the other four categories does not add much-if anything at all-to the analysis. The cleavage within the European trade union movement is above all a matter of the gap between the Nordic unions with their strong organizations and robust collective bargaining systems and the rest. Hand in hand with this we find lower levels of inequality and relatively high standards of living in the Nordic region. The German unions were for a long time rather strong-although not as strong as the Nordic-but their position was undermined by member and power losses and it was then time for another attitude to and interpretation of the need for minimum wage legislation. 
As mentioned previously, solidarity is a concept that can refer to very different phenomena (Gumbrell-McCormick and Hyman 2001; Hyman 2002). Obviously, the unions that are against minimum wage legislation focus on what they see as the best for employees in their own country/countries. It is with them they feel solidarity. The unions that are in favour of legislation do the same, but they have another country or other countries in mind. The positive and the negative side more or less stand against each other, as they feel that the counterpart can negatively impact on what they have. It has evidently been difficult to bridge the gap between the two. The ETUC compromise currently appears to be the only way to handle the cleavage in the European trade union movement.

At present, there is no indication that the Nordic countries would be about to introduce statutory minimum wages. One reason for this is that the key trade unions for the most part have a very negative attitude. It has also been shown that the organizations just below the confederate level are similarly negative (Furåker 2017). The crucial question is however what will happen in the long run. There are constantly new initiatives in Europe to introduce statutory minimum wages. The Laval verdict by the European Court of Justice some years ago implies certain drawbacks of not having legislated minima (e.g., Skedinger 2008: 28-29; Woolfson et al. 2010). Without this kind of regulation, unions' possibilities of industrial action are circumscribed. We cannot expect the Nordic collective bargaining model to be extended to other European countries, because the trade unions in these countries are too weak and show a tendency to become even weaker (Visser 2019). A similar decline also takes place in the Nordic region and this does not facilitate the spread of their system with negotiations between strong social partners. Even though the Council of Nordic Trade Unions weighs heavily in the European arena, other labour organizations still make up the majority; what the Nordic unions can do is essentially to fight for the preservation of a collective bargaining model that so far has served them fairly well. 


\section{Notes}

1. The first item in Table 3.1 had the response option 'Only to a low degree'. The remaining items presented in this chapter just had the option 'To a low degree'.

2. LO is a short form for Landsorganisationen, the large Swedish confederation for trade unions of manual workers.

\section{References}

Ahrne, G., and N. Brunsson. 2008. Meta-organizations. Cheltenham: Edward Elgar.

Bonin, H., I.E. Isphording, A. Krause-Pilatus, A. Lichter, N. Pestel, and U. Rinne. 2019. The German Statutory Minimum Wage and Its Effects on Regional Employment and Unemployment. Bonn: IZA Institute of Labor Economics.

Bruttel, O. 2019. The Effects of the New Statutory Minimum Wage in Germany: A First Assessment of the Evidence. Journal for Labour Market Research 53 (10). https://doi.org/10.1186/s2651-019-0258-z.

Caliendo, M., C. Schröder, and L. Wittbrodt. 2018. The Causal Effects of the Minimum Wage Introduction in Germany: An Overview. SOEP Papers on Multidisciplinary Panel Data Research, No. 1018. Berlin: Deutsches Institut für Wirtschaftsforschung.

Dølvik, J.E. 2013. Grunnpilarene $i$ de nordiske modellene. Et tillbakeblikk på arbeidslivs- og velferdsregimenes utvikling. NordMod 2030. Delrapport 1. Oslo: Fafo.

Eldring, L., and K. Alsos. 2012. European Minimum Wage: A Nordic Outlook. Report 2012:16. Oslo: Fafo.

Eldring, L., and K. Alsos. 2015. Statutory Minimum Wage Regulation in Europe: A Necessary Evil? Oslo: Fafo.

ETUC. 2007. Strategy and Action Plan, 2007-2011. Brussels: ETUC.

ETUC. 2011a. Draft Reflection Paper for the Winter School: The ETUC Path towards a Future for Growth and Employment through Alternative Integration Policies, Agenda Item 5. Executive Committee (EC195/EN/5). Brussels: ETUC. 
ETUC. 2011b. Preparation of the Winter School, Agenda Item 7. Executive Committee (EC196/EN/7). Brussels: ETUC.

ETUC. 2012a. A Social Compact for Europe. Brussels: ETUC.

ETUC. 2012b. Conclusions of the Copenhagen Winter School, Agenda Item $4 a$. Executive Committee (EC/197/EN4a). Brussels: ETUC.

ETUC. 2013. ETUC Position on the Social Dimension of the European Union. www.etuc.org/documents/etuc-position-social-dimension-europeanunion\#.

ETUC. 2015a. ETUC Action Programme 2015-2019. Available at: www.etuc. org/sites/www.etuc.org/files/publication/files/ces-congrecs_2015-rapportuk-ld_def_0.pdf.

ETUC. 2015b. Paris Manifesto. Brussels: ETUC.

ETUC. 2018. ETUC Resolution on Priorities for the Coordination of Collective Bargaining and Wage Policies. Brussels: ETUC.

Eurofound. 2015. Denmark: Heated Debate About Introducing Minimum Wage. www.eurofound.europa.eu/publications/article/2015/denmarkheated-debate-about-introducing-minimum-wage.

Eurofound. 2019a. Minimum Wages in 2019: Annual Review. Dublin: European Foundation for the Improvement of Living and Working Conditions.

Eurofound. 2019b. To Have or Have Not: A Statutory Minimum Wage. www. eurofound.europa.eu/publications/article/2019.

Fernández-Marcías, E., and C. Vacas-Soriano. 2016. A Coordinated European Union Minimum Wage Policy? European Journal of Industrial Relations 22 (2): 97-113.

Ferner, A., and R. Hyman (eds.). 1998. Changing Industrial Relations in Europe. Oxford: Basil Blackwell.

Furåker, B. 2017. The Issue of Statutory Minimum Wages: Views Among Nordic Trade Unions. Economic and Industrial Democracy. https://doi.org/ 10.1177/0143831X17711769.

Furåker, B., and M. Bengtsson. 2013. On the Road to Transnational Cooperation? Results from a Survey of European Trade Unions. European Journal of Industrial Relations 19 (2): 161-177.

Furåker, B., and K. Lovén Seldén. 2013. Trade Union Cooperation on Statutory Minimum Wages? A Study of European Trade Union Positions. Transfer: European Review of Labour and Research 19 (4): 507-520.

Georgiadis, A., I. Kaplanis, and V. Monastiriotis. 2018. Greece after the Bailouts: The Impact of Minimum Wages on Wages and Employment. Evidence from Greece. GreeSE-Hellenic Observatory Papers on Greece and Southeast Europe 131, Hellenic Observatory, LSE. 
Gumbrell-McCormick, R., and R. Hyman. 2001. International Trade Union Solidarity and the Impact of the Crisis. Stockholm: Sieps (Swedish Institute for European Policy Studies).

Gumbrell-McCormick, R., and R. Hyman. 2013. Trade Unions in Western Europe. Hard Times, Hard Choices. Oxford: Oxford University Press.

Gumbrell-McCormick, R., and R. Hyman. 2015. International Trade Union Solidarity and the Impact of the Crisis. European Policy Analysis 2015:1. Stockholm: Swedish Institute for European Policy Studies (SIEPS).

Hyman, R. 2002. Where Does Solidarity End? Eurozine, September 17.

Larsson, B., M. Bengtsson, and K. Lovén Seldén. 2012. Transnational Trade Union Cooperation in the Nordic Countries. Management Revue. The International Review of Management Studies 23 (1): 32-48.

Lehndorff, S., H. Dribbusch, and T. Schulten. 2017. European Trade Unions in a Time of Crises-An Overview. In Rough Waters. European Trade Unions in a Time of Crises, ed. S. Lehndorff, H. Dribbusch, T. Schulten, 7-35. Brussels: ETUI.

Lovén Seldén, K. 2014. Europafacklig samverkan. Problem och möjligheter. University of Gothenburg: Department of Sociology and Work Science.

McGuinness, S., and P. Redmond. 2018. Estimating the Effect of an Increase in the Minimum Wage on Hours Worked and Employment in Ireland. Bonn: IZA Institute of Labor Economics.

Nordic Labour Journal. 2015. February. www.nordiclabourjournal.org/i-fokus/ in-focus-2015/minimum-wage-for-the-nordic-region/article.2015-02-04. 3967575868.

OECD. 2014. Economic Policy Reform 2014: Going for Growth Interim Report. Paris: OECD.

Schulten, T. 2008. Towards a European Minimum Wage Policy? Fair Wages and Social Europe. European Journal of Industrial Relations 14 (4): 421-439.

Schulten, T. 2014. Contours of a European Minimum Wage Policy. Berlin: Friedrich Ebert Stiftung.

Schulten, T., and T. Müller. 2014. Back on the Agenda: A European Minimum Wage Standard. Policy Brief, No. 8/2014. Brussels: ETUI. www.etui.org/ Publications2/Policy-Briefs/European-Economic-Employment-and-SocialPolicy/Back-on-the-agenda-a-European-minimum-wage-standard.

Schulten, T., and A. Watt. 2007. European Minimum Wage Policy-A Concrete Proposal for a Social Europe. European Economic and Employment Policy Brief, No. 2-2007. Brussels: ETUI. 
Schulten, T., T. Müller, and L. Eldring. 2015. Prospects and Obstacles of a European Minimum Wage Policy. In Wage Bargaing Under the New European Economic Governance: Alternative Strategies for Inclusive Growth, ed. G. Van Gyes and T. Schulten, 327-359. Brussels: ETUI.

Seeliger, M. 2019. Trade Unions in the Course of European Integration: The Social Construction of Organized Interests. London and New York: Routledge.

Skedinger, P. 2008. Sweden: A Minimum Wage Model in Need of Modification? IFN Working Paper, No. 774.

Traxler, F., S. Blaschke, and B. Kittel. 2001. National Industrial Relations in Internationalized Markets: A Comparative Study of Institutions, Change, and Performance. Oxford: Oxford University Press.

Vande Keybus, L. 2012. Minimum Wages in Europe: A Strategy Against WageDumping Policies? Global Labour Column 86 (February).

Vaughan-Whitehead, D. 2010. Towards an EU Minimum Wage Policy? In The Minimum Wage Revisited in the Enlarged EU, ed. D. Vaughan-Whitehead, 509-530. Cheltenham, UK: Edward Elgar.

Visser, J. 2019. ICTWSS Database. Version 6.0. Amsterdam: Amsterdam Institute for Advanced Labour Studies (AIAS), University of Amsterdam.

Visser, J., M. Beentjes, M. van Gerven, and V. Di Stasio. 2009. The Quality of Industrial Relations and the Lisbon Strategy. Industrial Relations in Europe 2008, 45-72. Brussels: European Commission.

Woolfson, C., C. Thörnqvist, and J. Sommers. 2010. The Swedish Model and the Future of Labour Standards after Laval. Industrial Relations Journal 41 (4): 333-350. 
Open Access This chapter is licensed under the terms of the Creative Commons Attribution 4.0 International License (http://creativecommons.org/ licenses/by/4.0/), which permits use, sharing, adaptation, distribution and reproduction in any medium or format, as long as you give appropriate credit to the original author(s) and the source, provide a link to the Creative Commons license and indicate if changes were made.

The images or other third party material in this chapter are included in the chapter's Creative Commons license, unless indicated otherwise in a credit line to the material. If material is not included in the chapter's Creative Commons license and your intended use is not permitted by statutory regulation or exceeds the permitted use, you will need to obtain permission directly from the copyright holder.

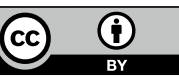

